\title{
Evaporative Tunnel Cooling of Dairy Cows in the Southeast. I: Effect on Body Temperature and Respiration Rate ${ }^{1}$
}

\author{
T. R. Smith, ${ }^{2}$ A. Chapa, ${ }^{\star}$ S. Willard, ${ }^{\star}$ C. Herndon Jr.,† R. J. Williams, ${ }^{\star}$ J. Crouch, ${ }^{\star}$ T. Riley,‡ and D. Pogueł \\ *Department of Animal and Dairy Sciences, and \\ †Department of Agricultural Economics, Mississippi State University, Starkville 39762 \\ $\ddagger$ North Mississippi Branch Experiment Station, Holly Springs 38635
}

\section{ABSTRACT}

The techniques used to mitigate the effects of heat stress on lactating dairy cows are often overwhelmed in the southeastern United States, where elevated heat and humidity often persist for extended periods. A model free-stall barn located at the North Mississippi Branch Experiment Station in Holly Springs was used to evaluate the potential of tunnel ventilation with evaporative cooling to alleviate heat stress in lactating dairy cows. Two studies were conducted using 2 groups of 10 lactating Holsteins housed in the tunnel barn (inside) and 2 groups of matched herdmates housed in an adjacent covered free-stall barn (outside), which was cooled by fans and sprinklers during 2001 or by shade and fans alone in 2003. Peak daytime temperatures inside were $5.2 \pm 0.18^{\circ} \mathrm{C}$ below that outside in 2001 and $3.1 \pm 0.20^{\circ} \mathrm{C}$ lower in 2003 . Although evaporative cooling increased humidity by $22 \%$, cows housed in the tunnel barn received $84 \%$ less exposure to moderate heat stress (temperature-humidity index $>80$ ) in both years. Cooling cows with evaporative tunnel ventilation reduced respiration rates by $15.5 \pm 0.56$ breaths $/ \mathrm{min}$ and rectal temperatures by $0.6 \pm 0.02^{\circ} \mathrm{C}$ compared with shade and fans alone in 2003. Cooling cows with evaporative tunnel ventilation reduced respiration rates by $13.1 \pm 0.78 \mathrm{breaths} / \mathrm{min}$ and rectal temperatures by 0.4 $\pm 0.03^{\circ} \mathrm{C}$ compared with fans and sprinklers in 2001 . Thus, tunnel ventilation cooling dramatically reduced the exposure to heat stress and improved the comfort of lactating dairy cows when compared with traditional cooling technologies under the conditions present in the southeastern United States.

Key words: heat stress, tunnel ventilation, evaporative cooling, dairy housing

\footnotetext{
Received October 11, 2005.

Accepted March 1, 2006.

${ }^{1}$ Approved for publication as Journal Article No. J-10799 of the Mississippi Agricultural and Forestry Experiment Station, Mississippi State University.

${ }^{2}$ Corresponding author: TRSmith@ads.msstate.edu
}

\section{INTRODUCTION}

\section{Heat Stress}

The effects of heat stress are a concern for producers throughout much of the United States; however, in the southeastern region, where sustained periods of elevated temperatures are often exacerbated by elevated ambient humidity, heat stress has a dramatic effect on the dairy industry (Ingraham et al., 1975; Baeta et al., 1987). The response to increased heat load in lactating cows includes increased respiration rates and reduced activity and feed intake (Fuquay, 1981; Hahn, 1999; West, 2003). Although these adaptations can minimize heat production and maximize its dissipation, they are not always conducive to production. Consequently, milk production and milk quality decline dramatically in the southeastern United States during the summer months and do not recover until cooler weather returns in the fall.

Techniques used to alleviate the impact of heat stress in dairy cattle include shade, fans, sprinklers, and dietary modifications (Beede and Collier, 1986; Huber et al., 1993; Chan et al., 1997), but these cooling methods are often overwhelmed during periods of severe heat stress in the southern United States. In addition, these methodologies often have secondary complications; excessive dietary protein can exacerbate the effects of heat stress (West, 2003) and excess water from misters and cooling ponds may increase the incidence of mastitis (Flamenbaum et al., 1986). Thus, the dairy industry is continually searching for more effective and economical cooling strategies. Evaporative cooling alone has yielded variable results (Frazzi et al., 2002). Brown et al. (1974) conducted a multiyear trial of a "pad-andfan" system in an open-sided free-stall barn. The evaporative cooling system consistently reduced respiration rates compared with cooling with fans and shade alone, but the effects on body temperature were not consistent. One drawback of fan-based systems is that for efficient cooling, cows must move into the airflow. This is greatly facilitated by the use of tunnel ventilation technology. 


\section{Tunnel Ventilation}

Tunnel ventilation technology is relatively new to the dairy industry, but is used extensively for cooling swine and poultry houses. Characterized as having air inlets at one end and exhaust fans at the other (Gooch and Stowell, 2003; Tyson et al., 2004), tunnel ventilation barns work to enhance convective heat loss by removing excess heat and humidity from the immediate surroundings of the animals. Tunnel ventilation alone can provide adequate supplemental cooling in temperate environments (Stowell et al., 2001; Gooch and Stowell, 2003), but in regions where additional cooling is required, this technology can be combined with other cooling methodologies such as misters or evaporative cooling pads (Turner et al., 1991). By reducing the temperature of incoming air, evaporative coolers work to further promote the ability of the cow to dissipate excess heat.

Studies of evaporative tunnel cooling (tunnel ventilation with supplemental evaporative cooling) demonstrate that this technology can provide superior cooling and growth performance in swine (Fehr et al., 1983) and poultry (Simmons and Deaton, 1988), but there are few reports evaluating its effects on heat stress in lactating dairy cows. Huhnke et al. (2001) reported that evaporative cooling could reduce the time of exposure to conditions of heat stress, but speculated that its benefits would be limited to less humid environments. Brouk et al. (2003a) studied the effect of evaporative tunnel cooling in lactating dairy cows in northeast Missouri and reported that respiration rates and rectal temperatures were reduced when compared with cooling with tunnel ventilation alone. Thus, there are few reports on the performance of evaporative tunnel cooling in the southeastern United States and none comparing its efficacy to traditional cooling techniques (shade, fans, and sprinklers). The objective of this study was to evaluate the efficacy of evaporative tunnel ventilation for cooling dairy cows in the southeastern United States.

\section{MATERIALS AND METHODS}

\section{Evaporative Tunnel Ventilation Facility}

A model evaporative tunnel ventilation facility (tunnel barn) was constructed at the North Mississippi Branch Experiment Station in Holly Springs with feed bunks, water tanks, free-stall bedding areas, controlled lighting, and waste management flush tanks to support 20 mature Holstein dairy cows (Figure 1 ). The $27.5 \times 9.2$ $\mathrm{m}$ model barn was outfitted with two 7.6-m evaporative cooling cells (AeroTech Inc., Evans, GA) at one end and four 1.2-m, 1-horsepower exhaust fans (Advantage, AeroTech Inc.) at the other. Thus, fresh air was cooled as it entered the barn through the cooling cells and then flowed past the cows before being exhausted at the far end. The 4 exhaust fans were thermostatically controlled, set to come on sequentially at 18.3, 21.1, 23.9 , and $26.7^{\circ} \mathrm{C}$. The pumps used to cycle water over the cooling cells were set to come on at $21.1^{\circ} \mathrm{C}$. Along one side of the tunnel barn were free stalls for 20 cows, which were bedded with sand. Along the other wall were feed bunks and automatic water troughs. The entire barn was divided into 2 pens with a central gate. Walls of the tunnel barn were constructed of cinder blocks and the insulated ceiling ranged in height from 2.1 to $2.4 \mathrm{~m}$. Daylight at the research station ranged from 12.5 to $14.3 \mathrm{~h} / \mathrm{d}$ during the studies. Lighting within the tunnel barn was on a 12:12 $\mathrm{h}$ cycle and cows received additional ambient lighting through the windows that lined both sides of the barn. The floor was sloped at 1.5\% toward the rear access doors and baffles at the bottom of these doors allowed water from the flush tanks to flow out of the barn. Water from the cooling cells was drained into the flush tanks at a rate of 0.25 $\mathrm{L} / \mathrm{min}$ each. Cows were removed from their respective housing units for approximately $1 \mathrm{~h}$ twice daily for milking at 0200 and $1400 \mathrm{~h}$ and for approximately $30 \mathrm{~min}$ at 0800 and $1700 \mathrm{~h}$ for feeding and cleaning of bedding. Within the tunnel barn, the sand bedding was raked clean daily and fresh sand was added to the stalls every 2 wk. The effects of evaporative tunnel ventilation cooling were studied over 2 seasons (2001 and 2003), which differed in ambient conditions and in the strategy used to cool cows housed outside.

\section{Outside Free Stalls}

Outside free-stall housing units were open-sided permanent shelters, with $2.1-\mathrm{m}$ eaves and $3.7-\mathrm{m}$ vented ridges. The free-stall shelters were on one side of a 3.7$\mathrm{m}$ cement alleyway and on the other side were covered feed bunks and watering troughs. In both years studied, cows housed outside were cooled with 1.2-m, 1-horsepower fans (2 per group; Advantage) that operated continuously. During the 2001 season, cows housed outside received additional cooling from sprinklers ( 7 per group emitting $3 \mathrm{~L} / \mathrm{min}$ each), which were operated continuously between approximately 1000 and $2200 \mathrm{~h}$. The outside freestalls were bedded with rubber mats that were raked clean daily. Cows housed outside had access to dry exercise lots in the evenings from 1700 to $0200 \mathrm{~h}$. Additionally, all cows were removed from their housing units for approximately $1 \mathrm{~h}$ at 0200 and $1400 \mathrm{~h}$ for milking.

\section{The Cows}

In each year, 40 lactating Holsteins were randomly assigned to 1 of 4 groups, which were balanced for DIM, 


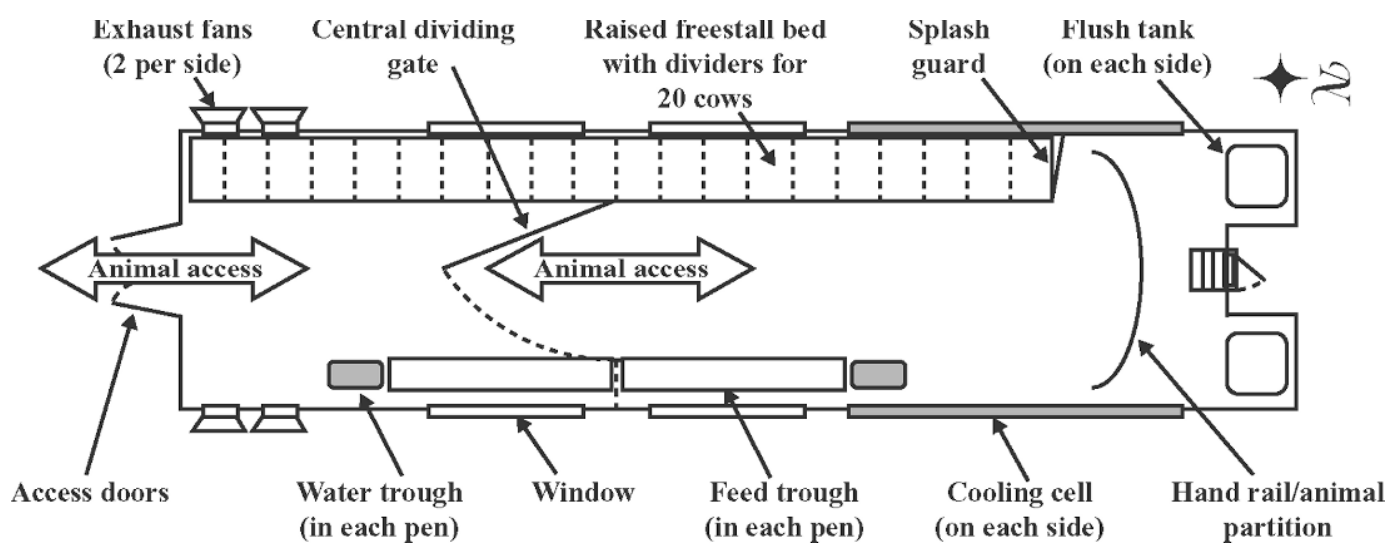

Figure 1. Floor plan and traffic pattern of the model evaporative tunnel ventilation facility (tunnel barn) at the North Mississippi Branch Experiment Station in Holly Springs. The $9.1 \times 27.4 \mathrm{~m}$ structure is fully self-contained with the capacity for housing 20 lactating dairy cows. The floor is sloped toward the animal access doors and a gap beneath these doors was fitted with a rubber flap, which allowed the barn floor to be cleaned using two 1,900-L flush tanks. The significant features shown are not to scale.

parity and production. Two groups were housed in the evaporative tunnel barn (inside group) and the remaining 2 groups were housed in an adjacent, naturally ventilated, free-stall barn (outside group). Ten-week lactation trials were conducted in $2 \mathrm{yr}$, from June 25 through September 3, 2001, and from May 26 through August 1, 2003. At the onset of the trial in 2001, parity was $2.3 \pm 0.18$ ( $\pm \mathrm{SE}$ ), DIM was $212 \pm 8.7$, BW was 671 $\pm 15 \mathrm{~kg}$, BCS was $3.1 \pm 0.10$ units and 305-d matureequivalent milk yield was $10,299 \pm 284 \mathrm{~kg}$. Similarly in 2003, parity was $2.1 \pm 0.15$, DIM was $213 \pm 7.0$, BW was $667 \pm 12 \mathrm{~kg}$, BCS was $3.6 \pm 0.09$ units and 305-d mature-equivalent milk was $10,861 \pm 226 \mathrm{~kg}$. There were no significant differences between treatment groups at the onset of the trial in either year. Additional details of the cows used are presented in the companion paper (Smith et al., 2006). All cows received a diet of $60.4 \%$ corn silage, $16.9 \%$ corn grain, $9.1 \%$ whole cottonseed, $8.4 \%$ soybean hulls, $2.4 \%$ vitamin and mineral premix, 2.1\% Prolak (HJ Baker and Sons, Inc., Stamford, CT), and 0.70\% Megalac (Church and Dwight Co. Princeton, NJ). Bermudagrass hay was added to the top of the diet at $0.91 \mathrm{~kg} / \mathrm{d}$ per cow. Cows were fed by pen twice daily to achieve $7 \%$ refusals, and fresh water was available at all times. The research protocols were approved by the Institutional Animal Care and Use Committee (IACUC approval \# 01-061).

\section{Environmental Measures}

Environmental temperature and humidity were recorded every 2 min in both housing units using Hobo (Onset Computer Corp., Pocasset, MA) monitors. The monitors were placed at 3 locations in the tunnel barn: near the cooling cells, at the central dividing gate, and at the exhaust fans. The recorder at the dividing gate was mounted on the ceiling ( $2.1 \mathrm{~m}$ high $)$, and the others were mounted on the wall at an elevation of $1.7 \mathrm{~m}$. Outside conditions were monitored by 2 recorders mounted midway in each shelter in the shade at an elevation of $1.83 \mathrm{~m}$. Wind and rainfall measurements were collected daily as part of routine meteorological monitoring at the experiment station.

\section{Animal Measures}

Rectal temperatures and respiration rates were measured 3 times weekly between 1400 and $1600 \mathrm{~h}$, while cows were in their respective housing units. If cows were out of the barn for any reason, they were allowed a minimum of $1 \mathrm{~h}$ to acclimate after returning before the physiological measurements were taken.

\section{Statistical Analysis}

Data were analyzed as a completely randomized design with repeated measures using the Mixed procedure of SAS (Version 9.1, Proc Mixed, SAS Institute, Cary, NC). Data for the $2 \mathrm{yr}$ were analyzed separately and the experimental unit was pen within barn, so the statistical design included the fixed effects of barn and pen as well as the random effect of week. A $P$-value of $<0.05$ was considered statistically significant. In the first year of the trial (2001), 1 cow from each pen inside the tunnel barn was diagnosed with a displaced abomasum during the first week of the trial and was removed from the trial without being replaced. Another 2 cows ( 1 outside and 1 inside) left the 2001 trial in the seventh week when they were dried off; their data were included in the analysis to the point where they left the trial. 
Table 1. Wind speed $(\mathrm{m} / \mathrm{s})$ in the tunnel ventilation barn ${ }^{1}$

\begin{tabular}{llll}
\hline & \multicolumn{3}{c}{ Position } \\
\cline { 2 - 4 } Elevation $(\mathrm{m})$ & Troughs & Middle & Freestalls \\
\hline 0.3 & $1.77 \pm 0.23$ & $2.09 \pm 0.14$ & $1.64 \pm 0.08$ \\
0.91 & $1.70 \pm 0.19$ & $2.34 \pm 0.07$ & $1.56 \pm 0.09$ \\
1.82 & $2.21 \pm 0.29$ & $2.59 \pm 0.17$ & $1.46 \pm 0.19$ \\
\hline
\end{tabular}

${ }^{1}$ Wind speed was measured with the barn fully occupied and all fans running. Data represent the mean $\pm \mathrm{SE}$ of 4 readings taken at both the cooling cells and dividing gate.

\section{RESULTS AND DISCUSSION}

\section{Airflow}

Wind speed in the tunnel barn (Table 1) was measured using a Kestrel 3000 (Nielsen-Kellerman, Boothwyn, PA) handheld meter, with all fans running and the barn fully occupied with cows. Wind speed measurements were taken at the south end of the cooling cells and at the central dividing gate. At each location, wind speed was measured at 3 sites across the floor (in the center and $1 \mathrm{~m}$ from either wall) and at 3 elevations $(0.3,0.91$, and $1.82 \mathrm{~m})$. To minimize the effect due to the position of cows in the barn, the wind speed measurements were replicated on 4 dates. Wind speed at the south end of the cooling cells averaged $1.83 \pm 0.08$ $\mathrm{m} / \mathrm{s}$ and was $11 \%$ greater at the dividing gate, where the ceiling was $0.3 \mathrm{~m}$ lower. At these locations, which represent the majority of the living area, wind speed was greatest down the middle of the barn, averaging $2.34 \pm 0.09 \mathrm{~m} / \mathrm{s}$, but remained at $1.89 \pm 0.14$ and 1.55 $\pm 0.07 \mathrm{~m} / \mathrm{s}$ over the troughs and freestalls, respectively. Wind speed was greatest at a height of $1.82 \mathrm{~m}$, averaging $2.08 \pm 1.6 \mathrm{~m} / \mathrm{s}$. Wind speed at an elevation of 0.91 $\mathrm{m}$, which would affect cows when standing, was $1.86 \pm$ $0.11 \mathrm{~m} / \mathrm{s}$; wind speed at an elevation of $0.3 \mathrm{~m}$, which would affect cows when lying down, averaged $1.84 \pm$ $0.10 \mathrm{~m} / \mathrm{s}$.

With all fans operating, wind speed in the tunnel ventilation barn was similar to the optimum of 1.3 to $2.2 \mathrm{~m} / \mathrm{s}$ for tie-stall barns reported by Tyson et al. (2004) and exceeded the value of $1 \mathrm{~m} / \mathrm{s}$ estimated to produce near maximal convective heat loss from cattle (Berman, 2004). Wind speed was, however, below the minimal critical speed of $2.04 \mathrm{~m} / \mathrm{s}$ recommended by Chastain and Turner (1994) for optimal heat flow from wetted bovine hair coats. Air exchange rate in the tunnel barn was calculated at $1,800 \mathrm{~L} / \mathrm{s}$ per cow, which is well above the current minimum recommendation of $220 \mathrm{~L} / \mathrm{s}$ for ventilating mature Holstein cows in hot weather (Bickert et al., 2000). Small "dead zones" were found $1 \mathrm{~m}$ from the north and south ends of the barn, where the air speed was $0.4 \pm 0.04 \mathrm{~m} / \mathrm{s}$ and $1.2 \pm 0.10 \mathrm{~m} / \mathrm{s}$, respectively. However, at the north end, the dead zone was not part of the animal living area; thus, airflow was acceptable for the majority of the animal living space.

\section{Evaporative Tunnel Cooling}

The temperature profile in the tunnel barn and the outside free stall barns on a representative day is shown in Figure 2. The temperature in the tunnel barn paralleled the outside temperature until the pumps began to circulate water over the cooling cells $\left(21.1^{\circ} \mathrm{C}\right)$. Although opening the rear "animal access" doors admitted warm air and reduced airflow through the barn, the temperature recorded at the cooling cells and the central dividing gate was unaffected even by long periods with the rear door open (data not shown). As a result, less than 2 min was required to reestablish airflow and decrease the temperature throughout the tunnel barn after closing the rear doors. Heat retained in the cinder-block walls of the tunnel barn along with heat from cows could have warmed the air as it passed down the barn. However, the model tunnel barn was relatively short and with the rapid air movement, there were no significant differences in temperature or humidity between replicate recorders in either barn so their observations were averaged.

During the 2001 season, the minimum and maximum ambient temperatures at the Holly Springs research station averaged $28.0 \pm 0.27$ and $38.2 \pm 0.29^{\circ} \mathrm{C}$, respectively. The 2003 trial was conducted earlier in the season and conditions were dramatically cooler, with minimum and maximum ambient temperatures of just 19.4 \pm 0.40 and $30.4 \pm 0.35^{\circ} \mathrm{C}$, respectively. Evaporative tunnel cooling had little effect on the minimum daily temperature (Figure $3 \mathrm{~A}$ ), which was $0.9 \pm 0.06^{\circ} \mathrm{C}$ below that in the outside freestalls in 2001 and was $0.4 \pm$ $0.15^{\circ} \mathrm{C}$ warmer in the 2003 season. However, it dramatically reduced the maximum daytime temperature inside the tunnel barn, which averaged $5.2 \pm 0.18$ and $3.1 \pm 0.20^{\circ} \mathrm{C}$ below the outside free-stall barns during the 2001 and 2003 seasons, respectively. Relative humidity (Figure 3B) contributed to the conditions of heat stress during the study and the evaporative cooling cells further increased the daytime relative humidity inside the tunnel barn by $23.3 \pm 0.55$ and $22.3 \pm 0.83 \%$ above that in the outside freestalls during the 2001 and 2003 trials, respectively. In addition to the ambient humidity, wind speed (Figure 3C) and rainfall (Figure 3D) affected the ability of cows to cool themselves, particularly those housed outside. Cooling efficiency of the tunnel barn can be measured as the reduction in the wet bulb temperature. Daytime cooling efficiency of the evaporative tunnel barn at Holly Springs was 83.5\%, which is typical of well-designed evaporative cooling facilities. 


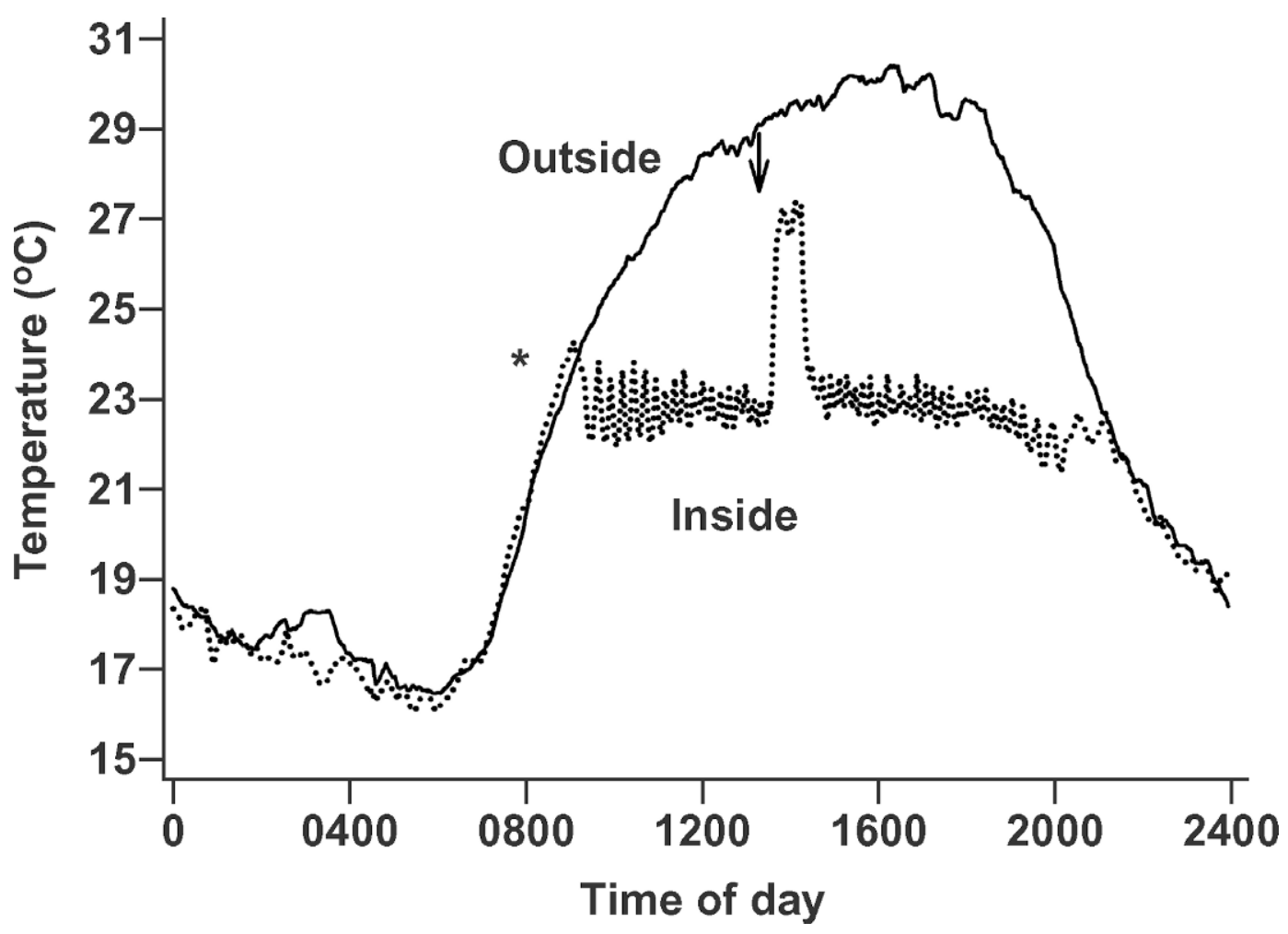

Figure 2. Daily temperature profile in the model evaporative tunnel ventilation barn (Inside; dotted line) and the adjacent naturally ventilated barn (Outside; solid line). Data were collected at 2-min intervals with all fans operating and both facilities fully occupied. The data recorders, mounted at an elevation of 1.7 to $1.8 \mathrm{~m}$, were located within the tunnel barn (at the exhaust fans) and in the shade of the outside free-stall barn. The asterisk indicates when water began cycling over the cooling cells (thermostatically set to $21.1^{\circ} \mathrm{C}$ ) and the arrow indicates when the access doors to the tunnel barn were opened. The maximum temperature difference between barns on this day was $7.1^{\circ} \mathrm{C}$. Opening of the rear access doors had no effect on the temperature recorded further inside the tunnel barn (data not shown).

The combined effects of temperature and humidity were characterized using the temperature-humidity index (THI; NOAA, 1967; Igono et al., 1992; Ravagnolo and Misztal, 2000). Tunnel ventilation reduced the maximum daily THI by 2.9 to 3.1 units and this increment had a dramatic impact on exposure to conditions of heat stress in both years studied (Figure 4). In the 2001 season, cows housed outside spent $335 \pm 32 \mathrm{~min} /$ $\mathrm{d}$ in conditions of moderate heat stress $(80<\mathrm{THI}<90)$ over the 10-wk study; this was reduced by $84 \%$ to $54 \pm$ $14 \mathrm{~min} / \mathrm{d}$ for cows housed in the tunnel barn. Consequently, the time of exposure to conditions of mild heat stress and thermoneutral conditions increased for cows housed in the tunnel barn. Exposure to mild heat stress $(72<\mathrm{THI}<80)$ increased $18 \%$ from $858 \pm 29 \mathrm{~min} / \mathrm{d}$ for cows housed outside to $1,011 \pm 43 \mathrm{~min} / \mathrm{d}$ for cows housed in the tunnel barn. Similarly, exposure to thermoneutral conditions (THI < 72) increased by $52 \%$, from 246 $\pm 35 \mathrm{~min} / \mathrm{d}$ for cows housed outside to $375 \pm 46 \mathrm{~min} /$ $\mathrm{d}$ for cows housed in the tunnel barn. There were no conditions of severe heat stress ( $\mathrm{THI}>90$ ) during either year studied.
The 2003 study was conducted earlier in the year and conditions were cooler (Figure 3A). Nevertheless, cows housed outside spent $206 \pm 31.8 \mathrm{~min} / \mathrm{d}$ in conditions of moderate heat stress during the study and this was reduced by $84 \%$ to $32 \pm 9.3 \mathrm{~min} / \mathrm{d}$ for cows housed in the tunnel barn (Figure 4). As with the 2001 trial, the reduction in exposure to conditions of moderate heat stress was accompanied by an increase in exposure to less stressful conditions. There was a $4 \%$ increase in exposure to conditions of mild heat stress from $697 \pm$ $37.8 \mathrm{~min} / \mathrm{d}$ for cows housed outside to $732 \pm 52.1 \mathrm{~min} /$ $\mathrm{d}$ for cows housed in the tunnel barn. Similarly, the exposure time to thermoneutral conditions was increased by $26 \%$ from $537 \pm 49.3 \mathrm{~min} / \mathrm{d}$ for cows housed outside to $676 \pm 56 \mathrm{~min} / \mathrm{d}$ for cows housed in the tunnel barn. The degree of environmental cooling achieved in the present study is similar to that in other reports of tunnel-ventilated facilities with evaporative coolers. Brouk et al. (2003a) reported that exposure to THI over 75 was reduced from 618 to $360 \mathrm{~min} / \mathrm{d}$ in Midwest dairy producer facilities fitted with evaporative tunnel cooling systems. 
2001
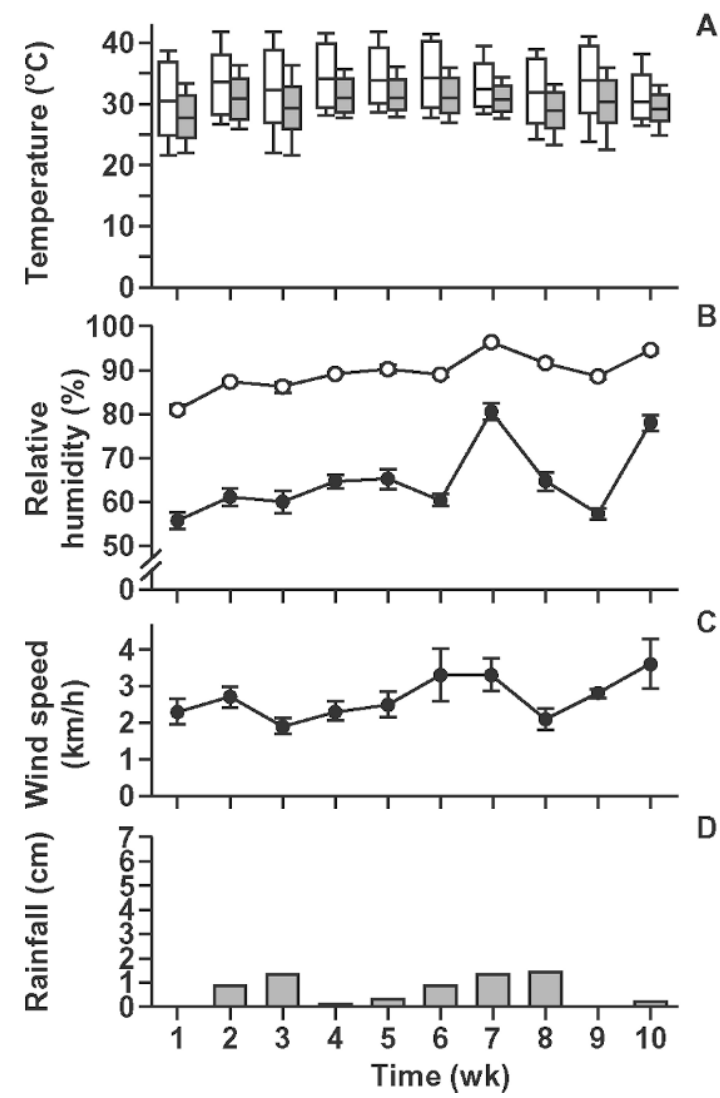

A
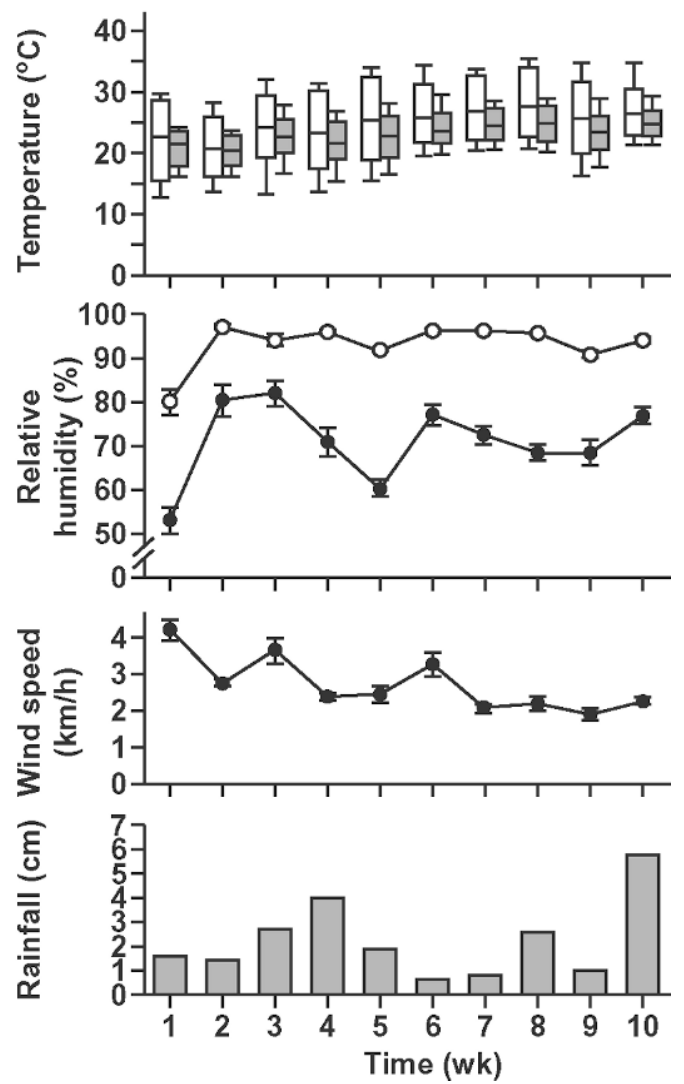

Figure 3. Environmental profile during 2 yr, including: A) Mean temperature in the evaporative tunnel ventilation barn (gray boxes) and in the naturally ventilated barn (open boxes). Data represent the weekly mean of daily high and low temperatures (box), mean temperature (center bar), and the temperature extremes (whiskers) within each barn; B) Daytime relative humidity in the evaporative tunnel ventilation barn $(\mathrm{O})$ and in the naturally ventilated barn $(\mathbf{O})$. Data represent the mean $\pm \mathrm{SE}$ of hourly observations between 1000 and $1600 \mathrm{~h}$ each day; C) Wind speed recorded at the experiment station in Holly Springs, MS. Data represent the mean \pm SD of daily observations; D) Weekly rainfall total recorded during the trials.

Although pad-and-fan cooling is capable of producing an 8 to $9^{\circ} \mathrm{C}$ reduction in environmental temperature (Timmons and Baugnman, 1983), the maximal daytime cooling was 3.1 to $5.2^{\circ} \mathrm{C}$ in the present study. Part of this difference in performance is due to the elevated ambient humidity in the region and the resulting decrease in the potential for evaporative cooling. However, the average daytime cooling was reduced as a result of data from cool days being included in the calculation.

Compared with sprinklers, cooling cells use substantially less water. To prevent the growth of mold on the cooling cells, water was bled off the cooling cells at a rate of $0.8 \mathrm{~L} / \mathrm{min}$ and was fed into the flush tanks. Even so, the total water use for cooling the tunnel barn averaged $1,152 \mathrm{~L} / \mathrm{d}$, which was $2.2 \%$ of that used by the sprinklers for cooling cows in the outside free-stall barns. When compared with other technologies, such as sprinklers, misters, and cooling ponds, evaporative tunnel cooling has the added advantage of minimizing the addition of excess water into the cow's environment.

\section{Rectal Temperature and Respiration Rate}

Rectal temperatures were not different between treatments during the first week of the trial in either year studied (Figure 5A). In 2001, as ambient temperatures increased, cows housed outside had a gradual increase in rectal temperatures, which peaked at wk 8 $\left(0.5 \pm 0.10^{\circ} \mathrm{C}\right.$ above that at wk $\left.1 ; P<0.0001\right)$. Conversely, rectal temperatures did not increase for cows housed in the tunnel barn (treatment $\times$ time interaction; $P<0.001$ ), but decreased throughout the trial period and during the final $4 \mathrm{wk}$ was $0.2^{\circ} \mathrm{C}$ below that during wk $1(P<0.01)$. The gradual decline in rectal temperatures for the cows housed in the tunnel barn probably resulted from the cows becoming accustomed to the measurement procedure. Nevertheless, com- 
2001
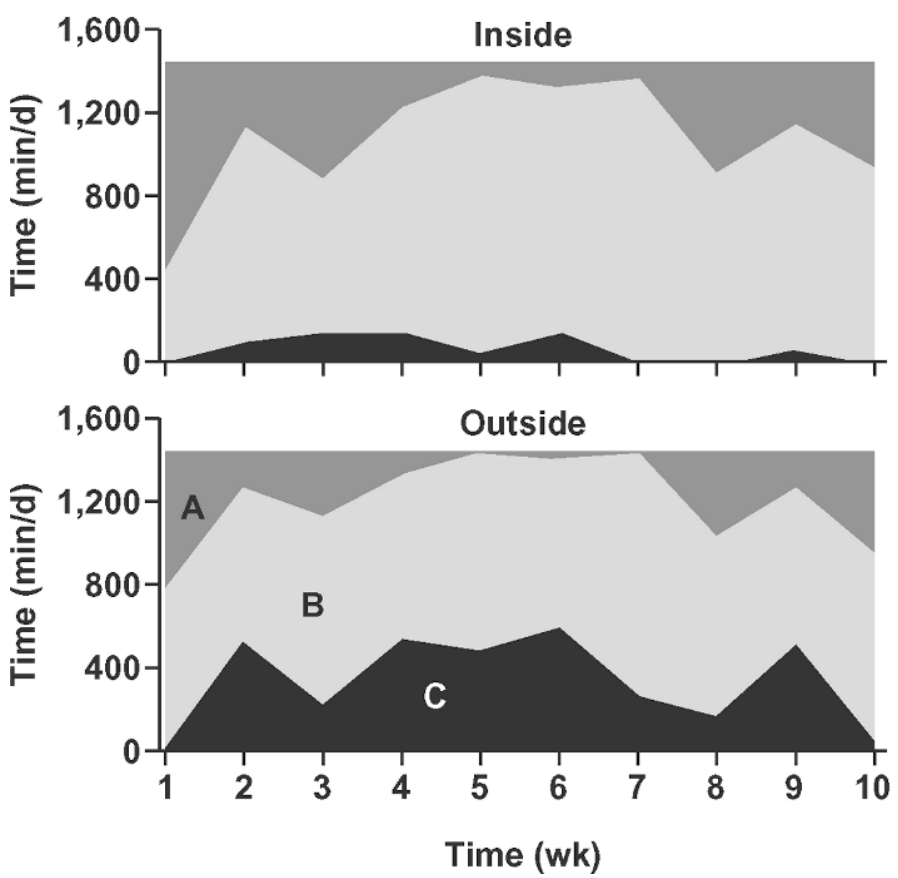

2003
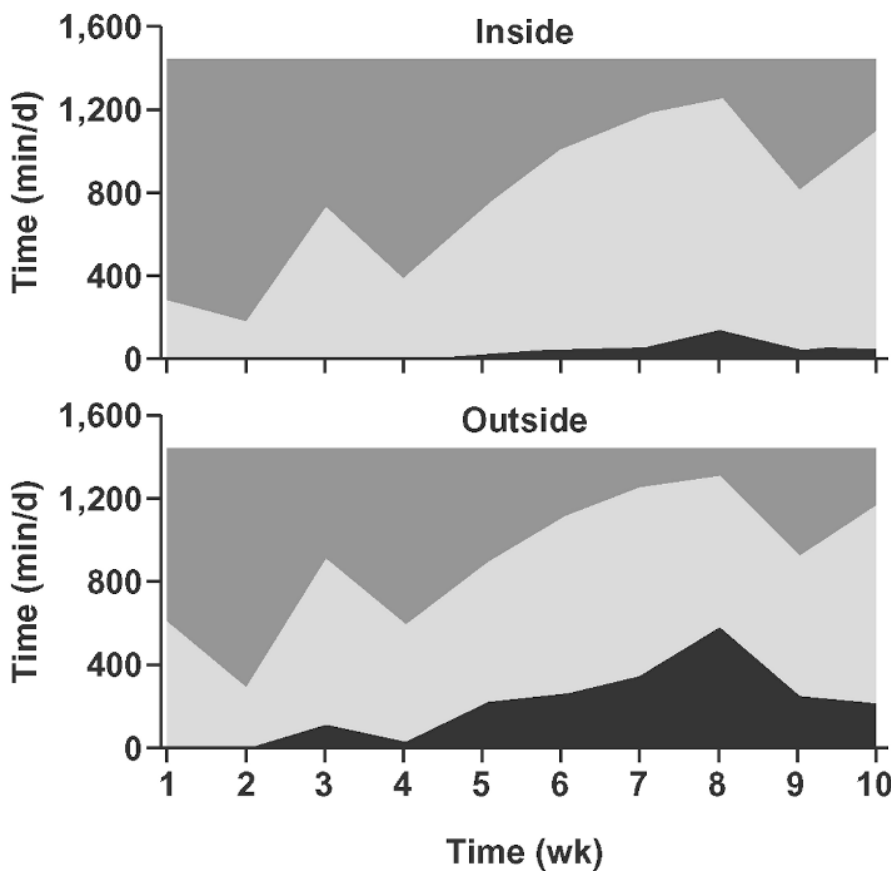

Figure 4. Mean daily exposure time (min/d) to thermoneutral (A), mild heat stress (B), and moderate heat stress (C) conditions for cows housed in the evaporative tunnel ventilation barn (Inside; upper panels) and in the adjacent, naturally ventilated barn (Outside; lower panels) for the $2 \mathrm{yr}$ studied. Heat-stress conditions were calculated using the temperature-humidity index $(\mathrm{THI})=\left[\left(0.8 \times{ }^{\circ} \mathrm{C}\right)+\mathrm{RH} / 100 \times\right.$ $\left.\left({ }^{\circ} \mathrm{C}-14.44\right)\right]+46.4$, where $\mathrm{RH}=$ relative humidity $(\%)$. Thermoneutral $(\mathrm{THI}<72)$, mild $(72<\mathrm{THI}<80)$, and moderate $(80<\mathrm{THI}<90)$ heat-stress ranges were assigned for lactating dairy cows according to Armstrong (1994). There were no conditions of severe heat stress (THI > 90) during either year of the trial.

pared with cooling with sprinklers and fans, evaporative tunnel cooling decreased the rectal temperature $0.4 \pm 0.03^{\circ} \mathrm{C}$ during the 2001 study $(P<0.0001)$. The difference between treatments was greatest at wk 7 , when the rectal temperature for cows housed in the tunnel barn was $0.6 \pm 0.12^{\circ} \mathrm{C}$ below that of cows housed outside $(P<0.0001)$.

During 2003, cows housed outside had a gradual increase in rectal temperatures with increasing environmental temperatures, which peaked at wk 7 at $1.1 \pm$ $0.05^{\circ} \mathrm{C}$ above that at wk 1 . However, rectal temperatures were unchanged for cows housed in the tunnel barn (treatment $\times$ time interaction; $P<0.001$ ). The difference between treatments was greatest at wk 8 , when the rectal temperature for cows housed in the tunnel barn was $1.0 \pm 0.05^{\circ} \mathrm{C}$ below that of cows housed outside $(P<0.0001)$. This coincided with a period of peak exposure to conditions of heat stress and moderate levels of humidity. Thus, compared with cooling with shade and fans alone, evaporative tunnel cooling decreased the rectal temperatures $0.6 \pm 0.02^{\circ} \mathrm{C}(P<$ 0.0001).

The afternoon respiratory rate was not different between treatment groups during the first week of the trial in either year studied (Figure 5B). In 2001, afternoon respiration rates increased for cows in both groups during the study period (linear effect of time; $P<0.0001$ ) in response to the warm weather, yet the increase was less for cows housed in the tunnel barn than for cows housed outside (treatment $\times$ time interaction; $P<$ 0.001). Compared with cooling with sprinklers and fans, evaporative tunnel cooling decreased the respiration rate $13.1 \pm 0.78$ breaths per minute (bpm) during 2001 $(P<0.0001)$. The difference between groups was greatest during wk 9, when the respiration rate for cows housed in the tunnel barn was $23.4 \pm 2.28 \mathrm{bpm}$ less than for cows housed outside $(P<0.0001)$.

In 2003, ambient temperatures increased as the study progressed, but the average temperature was lower than in 2001. As a result, the respiration rates of cows housed in the tunnel barn did not increase as the study progressed. However, for cows in the control group, which were cooled by shade and fans alone, the respiration rates increased gradually during the study period $(P<0.001)$. The difference between groups was $15.5 \pm 0.56 \mathrm{bpm}$ over the entire period $(P<0.0001)$ and was greatest during wk 10 , when the respiration rate for cows inside was $30.4 \pm 1.49 \mathrm{bpm}$ below that of control 
2001

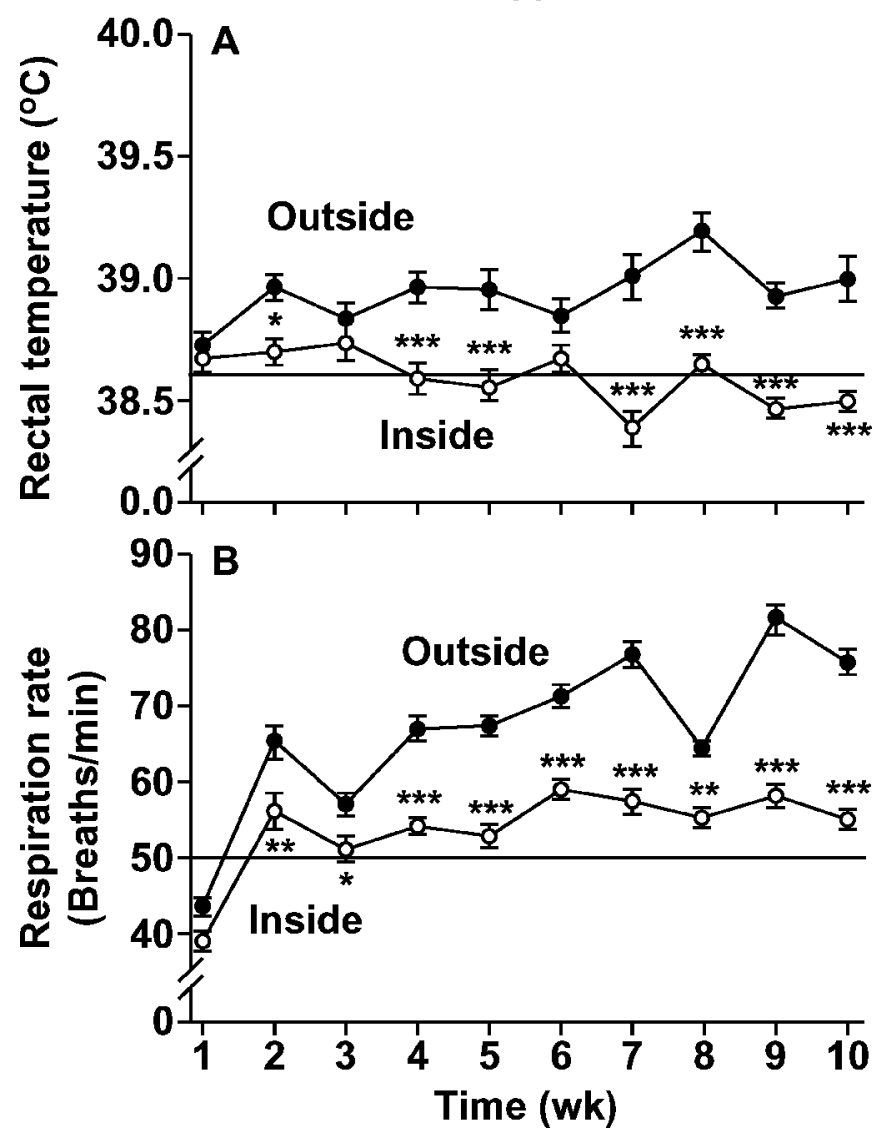

2003

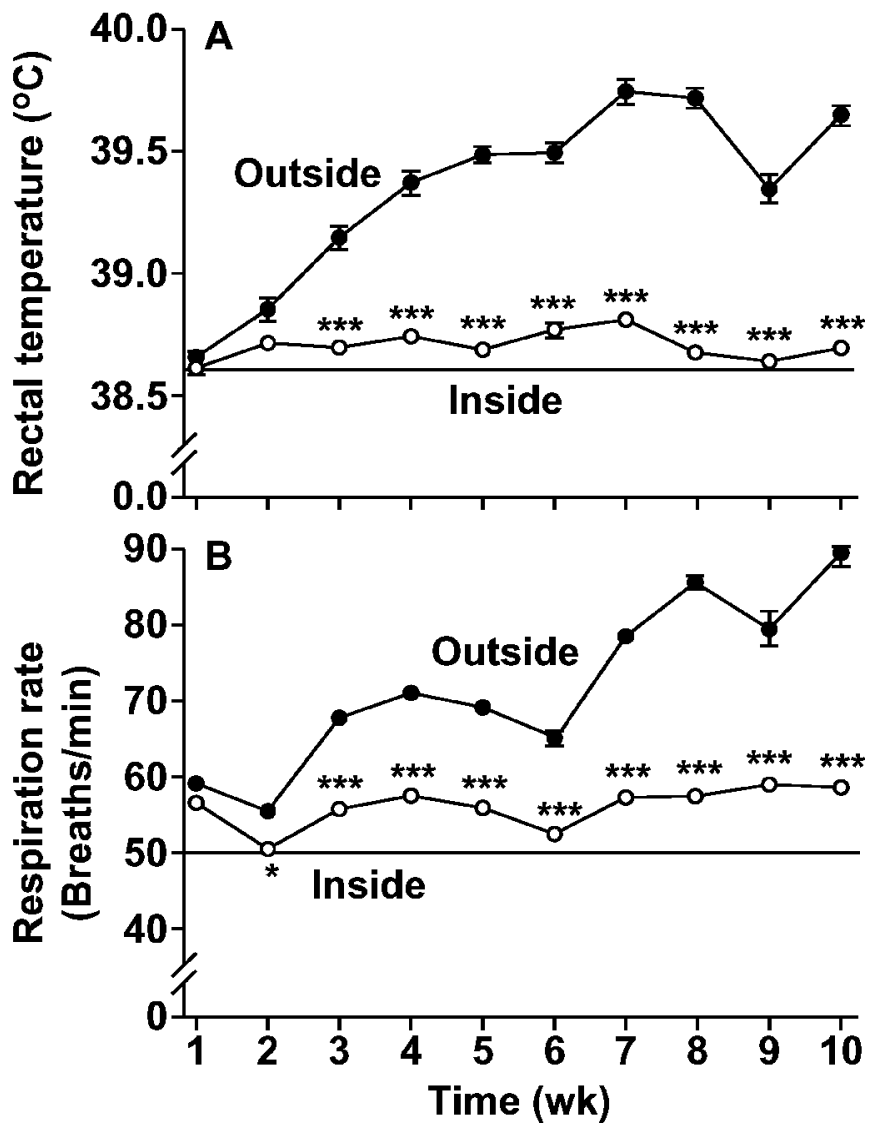

Figure 5. Weekly rectal temperature (A) and respiration rate (B) for lactating Holsteins housed in the evaporative tunnel barn (Inside; O) or in an adjacent, naturally ventilated barn (Outside; ). Data were collected from 1400 to $1500 \mathrm{~h}$ after animals had returned to their respective barns from evening milking for at least $1 \mathrm{~h}$. Values represent the mean ( \pm SE) of 3 observations per cow for each week. Significant differences between groups at each week are indicated by $* P<0.05, * * P<0.01$, and $* * * P<0.001$. The horizontal lines represent physiological norms for lactating dairy cows not under heat stress (Mount, 1979).

cows $(P<0.0001)$. In 2001 , heat stress peaked in wk 7 with $1,424 \pm 23 \mathrm{~min} / \mathrm{d}$ of exposure to mild or moderate heat stress and in 2003 heat stress peaked in wk 8 at $1,299 \pm 76 \mathrm{~min} / \mathrm{d}$. In both years the largest difference in the respiration rate between treatments occurred 2 wk after the period of greatest heat stress. It is interesting to note that for cows housed outside, the adaptation to heat stress seemed to include a gradual increase in the respiration rate throughout the study.

The impact of evaporative cooling alone has been studied with variable results. Brown et al. (1974) conducted multiyear trials of a pad-and-fan system in an open-sided free-stall barn during the warm season in northeast Mississippi. The evaporative cooling system consistently reduced respiration rates compared with cooling with fans and shade alone, but the effects on body temperature were variable. Frazzi et al. (2002) compared environmental and productive changes in response to cooling with fans and evaporative pads, fans and misters, fans and sprinklers, or shade alone for use in lactating dairy cows in southern Italy. They reported little effect of the cooling pads on rectal temperature and superior animal performance with the fan and sprinkler system. However, the cooling system used in their studies did not include tunnel ventilation and provided less air movement than in the present studies. These results demonstrate that the ability to cool the entire living area represents a significant advantage of tunnel ventilation technology over more traditional cooling systems, which require cows to move into the affected region. In comparing the impact of tunnel ventilation cooling alone or with supplemental evaporative cooling in northeast Missouri, Brouk et al. (2003a) reported that cows cooled with evaporative tunnel ventilation had lower respiration rates $(10.3 \mathrm{bpm})$ and rectal temperatures $\left(0.4^{\circ} \mathrm{C}\right)$ than cows cooled with tunnel ventilation alone. 


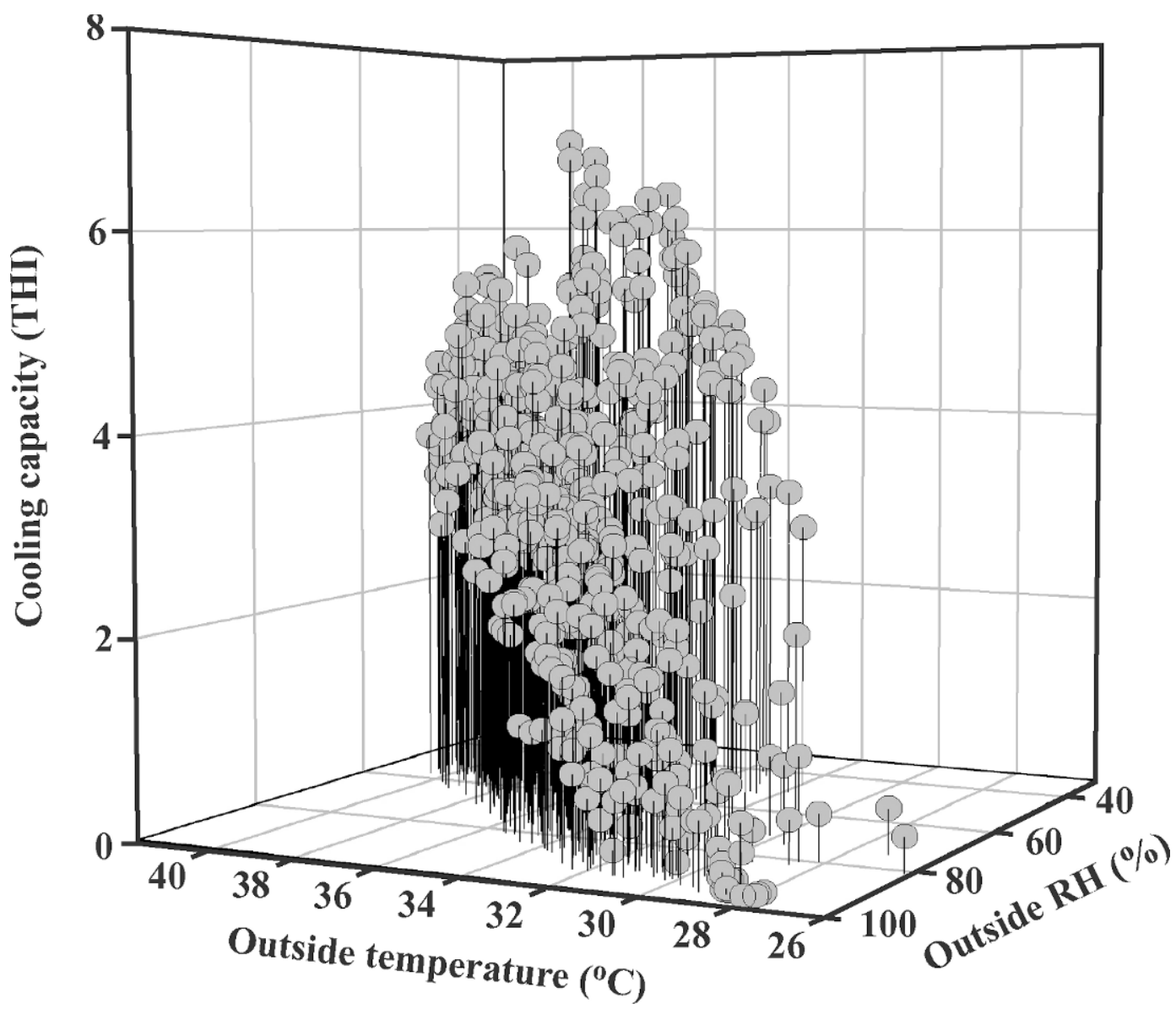

Figure 6. Impact of ambient temperature and relative humidity $(\mathrm{RH})$ on daytime cooling capacity [reduction in the temperature-humidity index (THI)] of the model evaporative tunnel facility at Holly Springs, MS. Data represent hourly means of daytime temperature, humidity, and cooling during the 2001 trial. Using these data, a regression equation was developed to predict the cooling capacity of evaporative tunnel ventilation from relative humidity: Cooling capacity $(\mathrm{THI})=8.823-0.0861 \times$ Outside $\mathrm{RH}(\%)\left(\mathrm{R}^{2}=0.80 ; P<0.0001\right)$. Addition of temperature to the equation did not improve the R-value.

\section{Reliability of Evaporative Tunnel Cooling}

One persistent question regarding evaporative cooling is whether it will function reliably in the southeastern United States given the conditions of elevated temperature and humidity. To characterize the reliability of evaporative tunnel cooling technology in the southeast, the cooling capacity of the model facility was plotted in relation to the ambient temperature and humidity (Figure 6). It was anticipated that cooling capacity would be reduced on overcast and rainy days, because of the low temperatures and elevated humidity; but on those days only minimal supplemental cooling is required. Similarly, the cooling capacity of the tunnel barn was minimal at night, but as daytime temperatures increased and relative humidity decreased, the tunnel barn was able to function. To confirm these observations, data for the daily maximal cooling capacity of the tunnel barn was correlated with the relative humidity (RH):

$$
\begin{aligned}
& \text { Cooling capacity }(\mathrm{THI})=8.823-0.0861 \\
& \times \text { Outside } \mathrm{RH}(\%)\left(\mathrm{R}^{2}=0.80 ; P<0.0001\right) .
\end{aligned}
$$

Equation 1 predicts that under the present environmental conditions, the maximum cooling in the tunnel barn was 8.8 THI units and it reflects the decreased cooling capacity at higher levels of RH. Addition of ambient temperature to the equation did not add significantly to the correlation, suggesting that under the conditions tested, the tunnel barn will cool whenever there is a drop in the $\mathrm{RH}$.

The relationship between ambient temperature and $\mathrm{RH}$ is described by the Clausius-Clapeyron equation (Adkins, 1983), which predicts that, within the range of environmental temperatures, $\mathrm{RH}$ will decrease an 
average of $3.8 \%$ for each degree Celsius that temperature increases. This relationship agreed closely with empirical data from the 2001 trial (Equation 2):

$$
d \mathrm{RH}=-3.74 \times d \mathrm{Temp}\left({ }^{\circ} \mathrm{C}\right)
$$

where $d \mathrm{RH}=$ change in $\mathrm{RH}$ and $d \mathrm{Temp}=$ change in temperature.

During the study, daytime heating was $10.5^{\circ} \mathrm{C}$ and equation 2 predicted that this would be associated with an approximate $39.3 \%$ drop in $\mathrm{RH}$. According to equation 1, this increment in daytime heating should allow the barn to reduce THI by approximately 3.6 units; the actual reduction in THI achieved in the current studies was $3.16 \pm 0.06$ units. Thus, data from the model facility suggest that the evaporative tunnel cooling technology was consistently able to provide cows with supplemental cooling whenever needed. The cooling capacity of an evaporative tunnel ventilation system is greater in conditions of low humidity (Brouk et al., 2003a), but even under the conditions present in northern Mississippi, this system dramatically reduced exposure to moderate heat stress and increased the time cows spent in thermoneutral conditions. These results are similar to those of Brouk et al. (2003b), who studied the function of evaporative tunnel facilities in Missouri and reported an afternoon temperature reduction of $4.6^{\circ} \mathrm{C}$ within their tunnel barn, which corresponded to a $30 \%$ increase in $\mathrm{RH}$ and a decrease of 3.25 units in THI.

\section{CONCLUSIONS}

When compared with cooling cows with fans and shade alone or with supplemental sprinklers, the evaporative tunnel cooling system reduced daytime THI in the tunnel barn by 3.0 units and this increment decreased exposure to conditions of moderate heat stress (THI > 80) by $80 \%$ in both years studied. Although elevated $\mathrm{RH}$ decreases the efficiency of evaporative tunnel cooling, $\mathrm{RH}$ levels dropped with daytime heating, which allowed the barn to function whenever supplemental cooling was needed. Over the $2 \mathrm{yr}$ studied in northeast Mississippi, evaporative tunnel cooling technology reliably decreased peak daytime rectal temperatures by 0.6 to $1.0^{\circ} \mathrm{C}$ and respiration rates by 20 to 30 bpm compared with traditional cooling strategies. By providing superior cooling, evaporative tunnel ventilation has the potential to reduce the effects of heat stress on dairy cattle in the southeast.

\section{ACKNOWLEDGMENTS}

This study was conducted as part of the S-299 Southern Regional Dairy Heat Stress Project. The authors wish to thank the Mississippi Agriculture and Forestry Experiment Station (MAFES) and the Mississippi State University Department of Animal and Dairy Sciences for their generous support of the research.

\section{REFERENCES}

Adkins, C. J. 1983. Chap. 10: Change of phase. Pages 180-212 in Equilibrium Thermodynamics. 3rd ed. Cambridge Univ. Press. New York, NY.

Armstrong, D. V. 1994. Heat stress interaction with shade and cooling. J. Dairy Sci. 77:2044-2050.

Baeta, C. F., N. F. Meador, M. D. Shanklin, and H. D. Johnson. 1987. Equivalent temperature index at temperatures above the thermoneutral for lactating dairy cows. ASAE Paper 87-4015. Am. Soc. Agric. Eng., St. Joseph, MI.

Beede, D. K., and R. J. Collier. 1986. Potential nutritional strategies for intensively managed cattle during thermal stress. J. Anim. Sci. 62:543-554.

Berman, A. 2004. Tissue and external insulation estimates and their effects on prediction of energy requirements of heat stress. J. Dairy Sci. 87:1400-1412.

Bickert, W. G., B. Holmes, K. Janni, D. Kammel, R. Stowell, and J. Zulovich. 2000. Building environment. Pages 77-91 in Dairy Freestall Housing and Equipment, MWPS-7. 7th ed. Midwest Plan Service, Iowa State University, Ames.

Brouk, M. J., J. F. Smith, and J. P. Harner, III. 2003a. Effect of utilizing evaporative cooling in tie-stall dairy barns equipped with tunnel ventilation on respiration rates and body temperatures of lactating dairy cattle. Pages 312-319 in Proc. 5th Int. Dairy Housing Conf. Am. Soc. Agric. Eng. Fort Worth, TX. Am. Soc. Agric. Eng., St. Joseph, MI.

Brouk, M. J., J. F. Smith, and J. P. Harner, III. 2003b. Effectiveness of cow cooling strategies under different environmental conditions. Pages 141-154 in Proc. 6th Western Dairy Management Conference, Reno, NV.

Brown, W. H., J. W. Fuquay, W. H. McGee, and S. S. Iyengar. 1974 Evaporative cooling for Mississippi dairy cows. Trans. ASAE 17:513-515.

Chan, S. C., J. T. Huber, K. H. Chen, J. M. Simas, and Z. Wu. 1997. Effect of ruminally inert fat and evaporative cooling on dairy cows in hot environmental temperatures. J. Dairy Sci. 80:1172-1178.

Chastain, J. P., and L. W. Turner. 1994. Practical results of a model of direct evaporative cooling of dairy cows. Pages 337-352 in Proc 3rd International Dairy Housing Conf. Am. Soc Agric. Eng., St. Joseph, MI.

Flamenbaum, I., D. Wolfenson, M. Mamen, and A. Berman. 1986. Cooling dairy cattle by a combination of sprinkling and forced ventilation and its implementation in the shelter system. J. Dairy Sci. 69:3140-3147.

Frazzi, E., L. Calamari, and F. Calegari. 2002. Productive response of dairy cows to different barn cooling systems. Trans. ASAE 45:395-405.

Gooch, C. A., and R. R. Stowell. 2003. Tunnel ventilation for freestall facilities - design, environmental conditions, cow behavior, and economics. Pages 227-234 in Proc. 5th International Dairy Housing Conference. Am. Soc. Agric. Eng. Fort Worth, TX. Am. Soc. Agric. Eng., St. Joseph, MI.

Hahn, G. L. 1999. Dynamic responses of cattle to thermal heat loads. J. Dairy Sci. 82(Suppl. 2):10-20.

Huber, J. T., Z. Wu, S. C. Chan, and K. H. Chen. 1993. Feeding for high production during heat stress. Pages 183-192 in Western Large Herd Management Conf. Las Vegas, NV.

Huhnke, R. L., L. C. McCowan, G. M. Meraz, S. L. Harp, and M. E. Payton. 2001. Determining the frequency and duration of elevated temperature-humidity index. Paper No. 01-4111. Am. Soc. Agric. Eng., Sacramento, CA.

Igono, M. O., G. Jotvedt, and H. T. Stanford-Crane. 1992. Environmental profile and critical temperature effects on milk production of Holstein cows in desert climate. Int. J. Biometeorol. 36:77-87. 
Ingraham, R. H., R. W. Stanley, and W. C. Wagner. 1975. Relationship of temperature and humidity to conception rate of Holstein cows in Hawaii. J. Dairy Sci. 59:2086-2090.

Mount, L. E. 1979. Adaptation to Thermal Environment. Man and His Productive Animals. Univ. Park Press, Baltimore, MD.

National Oceanic and Atmospheric Administration (NOAA). 1967. Livestock Hot Weather Stress Operations Lett. C31-76. US Dept Commerce, Natl. Weather Serv. Central Region, Kansas City, MO.

Ravagnolo, O., and I. Misztal. 2000. Genetic component of heat stress in dairy cattle, parameter estimation. J. Dairy Sci. 83:2126-2130.

Simmons, J. D., and J. W. Deaton. 1988. Research note: Evaporative cooling for increased production of large broiler chickens. Poult. Sci. 68:839-841.

Smith, T. R., A. Chapa, S. Willard, C. Herndon, R. J. Williams, J. Crouch, T. Riley, and D. Pogue. 2006. Evaporative tunnel cooling of dairy cows in the Southeast. II: Impact on lactation performance. J. Dairy Sci. 89:3915-3923.

Stowell, R. R., C. A. Gooch, and S. Inglis. 2001. Performance of tunnel ventilation for freestall dairy facilities as compared to natural ventilation with supplemental cooling fans. Pages 29-40 in Proc. 6th Int. Symp., Am. Soc. Agric. Eng. Louisville, KY. Am. Soc. Agric. Eng., St. Joseph, MI.

Timmons, M. B., and G. R. Baugnman. 1983. Experimental evaluation of poultry mist-fog system. Trans. ASAE 26:207-210.

Turner, L. W., R. C. Warner, J. P. Chastain, and H. F. Elder. 1991. Forced evaporative cooling of dairy cows: On-farm demonstration results. Paper 91-4023. Am. Soc. Agric Eng., Albuquerque, NM.

Tyson, J. T., R. E. Graves, D. F. McFarland, and T. Wilson. 2004 Tunnel ventilation for tie stall dairy barns. Coop. Ext. Pub. No. G 78. Penn State Univ. College of Agric. Sci., University Park.

West, J. W. 2003. Effects of heat-stress on production in dairy cattle. J. Dairy Sci. 86:2131-2144. 